\title{
Graphite Matrix Materials for Nuclear Waste Isolation
}

W. C. Morgan

June 1981

Prepared for the U.S. Department of Energy under Contract DE-AC06-76RLO 1830

Pacific Northwest Laboratory

Operated for the U.S. Department of Energy by Battelle Memorial Institute 


\title{
NOTICE
}

This report was prepared as an account of work sponsored by the United States Government. Neither the United States nor the Department of Energy, nor any of their employees, nor any of their contractors, subcontractors, or their employees, makes any warranty, express or implied, or assumes any legal liability or responsibility for the accuracy, completeness or usefulness of any information, apparatus, product or process disclosed, or represents that its use would not infringe privately owned rights.

The views, opinions and conclusions contained in this report are those of the contractor and do not necessarily represent those of the United States Government or the United States Department of Energy.

\section{PACIFIC NORTHWEST LABORATORY}

operated by

BATTELLE

for the

UNITED STATES DEPARTMENT OF ENERGY

Under Contract DE-AC06-76RLO 1830

\author{
Printed in the United States of America \\ Available from \\ National Technical Information Service \\ United States Department of Commerce \\ 5285 Port Royal Road \\ Springfield, Virginia 22151
}

Price: Printed Copy $\$$ *; Microfiche $\$ 3.00$

\begin{tabular}{cr} 
*Pages & \multicolumn{1}{c}{$\begin{array}{c}\text { NIS } \\
\text { Selling Price }\end{array}$} \\
$001-025$ & $\$ 4.00$ \\
$026-050$ & $\$ 4.50$ \\
$051-075$ & $\$ 5.25$ \\
$076-100$ & $\$ 6.00$ \\
$101-125$ & $\$ 6.50$ \\
$126-150$ & $\$ 7.25$ \\
$151-175$ & $\$ 8.00$ \\
$176-200$ & $\$ 9.00$ \\
$201-225$ & $\$ 9.25$ \\
$226-250$ & $\$ 9.50$ \\
$251-275$ & $\$ 10.75$ \\
$276-300$ & $\$ 11.00$
\end{tabular}




\section{5}

GRAPHITE MATRIX MATERIALS FOR NUCLEAR IVASTE ISOLATION

W. C. Morgan

June 1981

Prepared for

the U.S. Department of Energy under Contract DE-AC06-76RLO 1830

Pacific Northwest Laboratory Richland, Washington 99352 


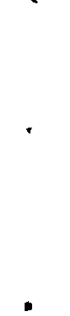


SUMMARY

The long-term storage of radioactive waste in geologic media requires that the radioisotopes be immobilized. Immobilization of the radioisotopes requires that they be fixed in a solid form which is physically and chemically stable. The multibarrier concept would provide additional assurance of immobilization by introducing one or more additional layers of containment between the waste body and the storage environment. The additional containment could be provided, for example, by coatings applied to the waste bodies, by embedding the bodies in an impermeable matrix, or by encapsulating the bodies in a sealed, impermeable, container. One obvious requirement of the containment material is that it must be physically and chemically inert when exposed to the storage environment, including the radiation field from the waste.

At low temperatures, graphites are chemically inert to all but the strongest oxidizing agents. The raw materials from which artificial graphites are produced are plentiful and inexpensive. Moreover, the physical properties of artificial graphites can be varied over a very wide range by the choice of raw materials and manufacturing processes. Manufacturing processes are reviewed herein, with primary emphasis on those processes which might be used to produce a graphite matrix for the waste forms.

The approach, recommended herein, involves the low-temperature compaction of a finely ground powder produced from graphitized petroleum coke. The resultant compacts should have fairly good strength, low permeability to both liquids and gases, and anisotropic physical properties. In particular, the anisotropy of the thermal expansion coefficients and the thermal conductivity should be advantageous for this application. With two possible exceptions, the graphite matrix appears to be superior to the metal alloy matrices which have been recommended in prior studies.

The two possible exceptions are the requirements on strength and permeability; both requirements will be strongly influenced by the containment design, including the choice of materials and the waste form, of the multibarrier package. Various methods for increasing the strength, and for decreasing the permeability of the matrix, are reviewed and discussed in the 
sections on "Incorporation of Other Materials" and "Elimination of Porosity." However, it would be premature to recommend a particular process until the overall multi-barrier design is better defined.

It is recommended that increased emphasis be placed on further development of the low-temperature compacted graphite matrix concept. 
CONTENTS

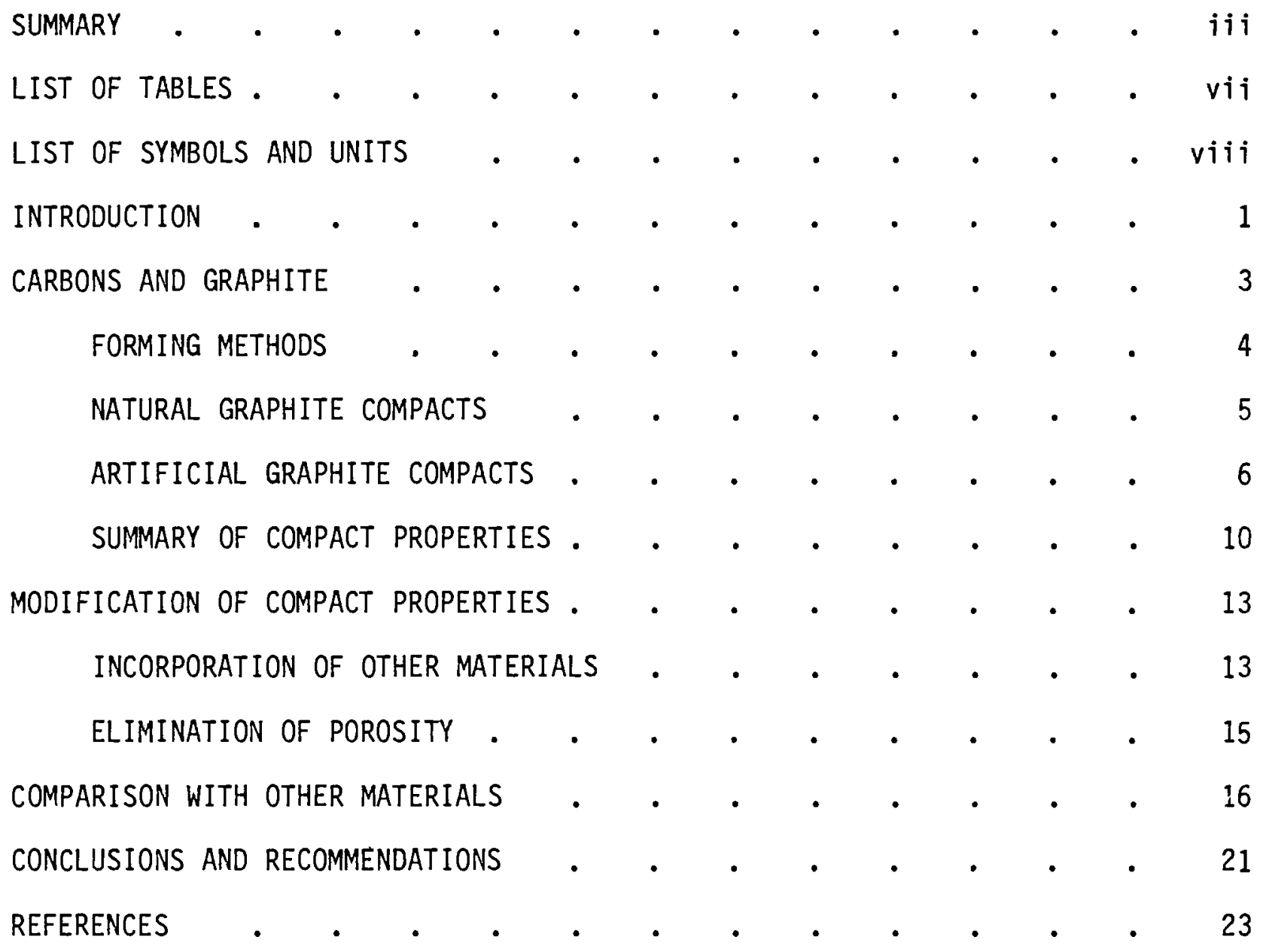

v 


\section{$\underline{\text { TABLES }}$}

1 Natural Graphite Compacts . . . . . . . . . . 11

2 Artificial Graphite Compacts . . . . . . . . 12

3 Comparison of Thermal Conductivities . . . . . . 18

4 Cost and Availability . . . . . . . . . . . . 19 


\section{LIST OF ABBREVIATIONS AND UNITS}

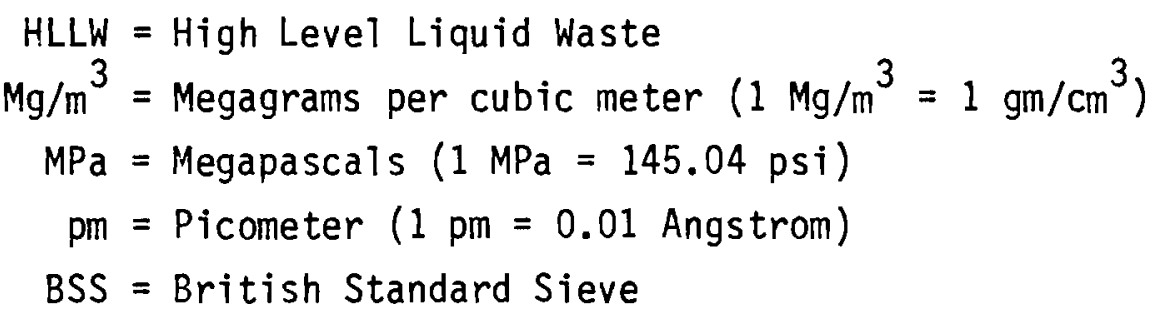




\section{INTRODUCTION}

This review was funded by the U.S. Department of Energy, Division of Waste Products, under the High Level Waste Immobilization Program (HLWIP). The primary objective of the HLWIP is to develop processes for converting High Level Liquid Waste from nuclear fuel reprocessing operations to forms which are suitable for long-term storage in geologic media. This requires that the radioisotopes be immobilized. One approach to immobilization of the radioisotopes is to fix them in a solid form which is physically and chemically inert; the borosilicate glasses ${ }^{(1-3)}$ (which are used as "the reference" waste form at the Pacific Northwest Laboratory) were developed around this concept. Another approach ${ }^{(a)}$ is to isolate the waste form from the storage environment through the use of multiple barriers; prior work at the Pacific Northwest Laboratory $(P N L)^{(4-6)}$ has considered waste-glass marbles and supercalcine (uncoated, glass-coated, and $C_{D}{ }^{(b)}$-coated) pellets encapsulated in a metal matrix. Depending on the metal (or alloy) and the waste form, the matrix was either vacuum-cast or gravity-sintered inside a stainless steel canister.

The chemical and physical properties of graphite are in many instances superior to those of metals; thus, it is logical to consider graphite as an alternate to metals for use as a matrix material. The purpose of this review is to determine the potential for use of graphite, in place of a metal, as the matrix material in a multiple barrier containment for radioactive wastes. Numerous other combinations of processes have been proposed $(7,8)$ for the fixation of radioactive wastes in a solid form; each of these combinations of processes varies both in regard to its technological complexity and in regard to the specific properties of the product waste form. (9) It is outside the scope of this review to compare the various options; however, some understanding of the possibility for trade-offs between process-complexity and product properties can be gained by considering the waste forms used in the previous work on metal matrices.

(a) These two concepts are not mutually exclusive.

(b) Chemical Vapor Deposition 
The "reference" waste form at PNL is a low-melting (1000 to $1150^{\circ} \mathrm{C}$ ) borosilicate glass, produced from High-Level Liquid Waste (HLLW). These glasses are produced by calcining HLLW, ${ }^{(a)}$ mixing with a suitable frit, melting (either "in-can" or in a continuous ceramic melter), and solidifying the resultant glass in the stainless steel canister in which it would be stored. Marbles have been produced by re-melting these simulated HLLW glasses or directly from the original glass melt.

"Supercalcine" pellets were produced by incorporating suitable additives in the liquid waste so that the pressed and sintered calcine developed a crystalline, rather than the vitreous, structure. The additives were chosen such that the crystals in which the radioactive isotopes are incorporated are more stable and leach resistant than are the glasses; however, the sintered calcine pellets are more porous than are the glasses. Coating(s) applied to the sintered pellets can reduce the accessible porosity and also serve as an additional barrier between the waste and the environment.

Both marbles and uncoated supercalcine pellets have been successfully encapsulated in various metallic matrices in $0.2 \mathrm{~m}$ diameter by $1.2 \mathrm{~m}$ long canisters, and marbles have been encapsulated in a lead matrix in $0.3 \mathrm{~m}$ diameter by $2.4 \mathrm{~m}$ long canisters.

Requirements for an ideal matrix material ${ }^{(10)}$ include:

1) Chemical or mechanical bonding to the waste bodies and to the canister walls,

2) High thermal conductivity, (b)

3) Physical and chemical stability in the radiation field from the waste,

4) Impermeability to moisture, and

5) Inertness when exposed to the storage environment.

(a) Preliminary studies were conducted using simulated (non-radioactive) HLLW; recently, actual HLLW is being used in some studies.

(b) May not be required for defense wastes or "old" high-level wastes. 
In addition, the matrix should provide a physical barrier between the waste bodies and between the waste bodies and the canister wall. Although availability and cost of the matrix material, ease and cost of fabricating the matrix, and strength (or impact resistance) are generally of less concern, (10) they must be considered in developing the criteria for final selection of both the matrix material and total waste-fixation package.

Graphite, the hexagonal crystalline form of carbon, represents an alternative to metals for use as the matrix material. At low temperatures it is chemically inert to all except the strongest oxidizing agents. Natural graphite occurs as a mineral in many different geologic formations, so its physical and chemical stability has, essentially, been demonstrated. Artificial (synthetic) graphite, and other forms of carbon can be manufactured from a wide variety of raw materials, and by various different processes. By choice of raw materials and manufacturing process the physical properties of the resultant graphite (or other form of carbon) can be varied over a wide range of values; $(11,12)$ in general, it can be said that in one form or another, carbon materials can meet all of the above requirements for a matrix material. The primary question is whether a single form can meet all of the requirements.

This review was undertaken to:

1) critically examine the alternate means by which a graphite (or carbon) matrix could be produced,

2) identify that (or those) combination(s) of raw materials and processes which could be used to produce an acceptable matrix material, and

3) recommend whether additional work should be done on graphite (carbon) matrices.

\section{CARBONS AND GRAPHITES}

The physical form of natural graphites depends on its genesis; the forms vary from the highly oriented crystalline veins of "natural flake graphite" to the cryptocrystalline masses known conmercially as "amorphous graphite." In the following sections any reference to "natural graphite" implies that the form is that of the crystalline natural flake graphite. 
Physical properties of artificial carbons and graphites are highly dependent on the state (solid, liquid, or gas) of the precursor material during pyrolysis. The chars, formed during pyrolysis of a solid, are generally hard and abrasive even after heating to "graphitization temperatures" (2400 to $3000^{\circ} \mathrm{C}$ ). In general, bodies made from the chars tend to have high strength, but very low thermal conductivities, compared to the cokes formed from pyrolysis of a liquid. Precursors which are fluid at the pyrolysis temperature generally form ordered regions which develop into highly crystalline graphite during heating to graphitization temperatures. Pyrolysis in the gas phase produces the fluffy forms of carbon known as soot, carbon black, thermal black, etc.; pyrolys is of a gas on a heated surface, however, results in generation of an impervious pyrocarbon layer which can be non-graphitizing, graphitizing, or graphitic, depending on the gas and deposition conditions.

\section{FORMING METHODS}

Most of the artificial graphite sold in this country is in the form of electrodes for the electric-steel industry. $(13,14)$ Normally, these electrographites are produced by mixing a calcined petroleum coke with coal-tar pitch; the mixture is then extruded, baked, and graphitized.

Generally, the cokes are the carbonaceous residues remaining from the delayed-coking of petroleum residues; cokes produced by the fluid-coking process have poor crystallinity after heating to graphitization temperatures and are not, therefore, used for electrographites. Calcination, at temperatures of $1100^{\circ}$ to $1400^{\circ} \mathrm{C}$, removes the remaining volatile hydrocarbons and shrinks the coke particles before they are ground and mixed with the binder material.

Coal-tar pitch, the residue from the distillation of coal-tar, is nomally used as a binder for the particles of coke; during baking (to $800-1000^{\circ} \mathrm{C}$ ), it pyrolyses leaving about 55 weight percent (as carbon) linking the coke particles. The evolved gases, amounting to some 10 to 12 percent of the weight of the extruded mix, leave a network of connected pores tracing their exit paths.

A cylinder which is molded, rather than extruded from the same coke-pitch mixture, will be somewhat more isotropic and will have higher strength and thermal conductivity in the radial direction. However, the baked body is very 
porous and its thermal conductivity will be only a few percent of the conductivity it would develop during heating to graphitization temperatures.

By using a pre-graphitized coke in place of the calcined coke, much higher thermal conductivity can be obtained in the baked state; however, this still results in a very porous material. Boeder and Fitzer ${ }^{(15)}$ have reviewed the literature on hot-working of graphites and reported the results of their own investigations using an extensive series of starting materials. Carmichael et al., (16) Chard and Niesz, ${ }^{(17)}$ and Kobayashi et al., $(18,19)$ have produced dense graphite bodies, containing no binder materials, by hot compaction of various carbon materials, including Thornel fibers, diamond dust, and ground powders of artificial graphites, petroleum cokes, glassy carbon. However, the temperatures which are required for hot-working or hot compaction are generally much higher than those to which the waste forms should be exposed; therefore, these techniques will not be discussed further.

\section{NATURAL GRAPHITE COMPACTS}

Several investigators $(20-23)$ have cold-compacted natural graphite to greater than 90 percent of the theoretical density of graphite crystals, but the first attempts to obtain compacts using artificial graphite powders, without binders, were unsuccessful. Wirtz ${ }^{(20)}$ reported that blocks $(3 \times 8 \times 5 \mathrm{~cm})$ with densities of 2.05 to $2.07 \mathrm{Mg} / \mathrm{m}^{3}$ had been formed (a) from purified natural graphite crystals (of German origin) by compressing a finely crushed powder at $290 \mathrm{MPa}$. Heating to $800-900^{\circ} \mathrm{C}$ "hardened" the blocks, and compressive strengths of $18 \mathrm{MPa}$ were obtained. Rusinko and Walker ${ }^{(21)}$ produced $13 \mathrm{~mm}$ diameter by $25 \mathrm{~mm}$ long cylinders of Ceylon natural graphite (Dixon's type 200-10) (b) with densities up to $2.01 \mathrm{Mg} / \mathrm{m}^{3}$ and compressive strengths up to $13.2 \mathrm{MPa}$ using a pressure of $860 \mathrm{MPa}$. Cohesive compacts were obtained at lower strength and density. Increasing the density by $26 \%\left(1.56 \mathrm{Mg} / \mathrm{m}^{3}\right.$ to $\left.1.97 \mathrm{Mg} / \mathrm{m}^{3}\right)$ resulted in a three fold increase in strength (4 MPa to $12 \mathrm{MPa}$ ).

(a) by the "Graphite Factory Kropfmiihl" in Munich, a supplier of natural graphite, in collaboration with the Max-Planck-Institute fuir Physik in Göttengen.

(b) Joseph Dixon Crucible Co., Jersey City, New Jersey. 
The specific surface areas of Rusinko and Walker's compacts $\left(11.3 \mathrm{~m}^{2} / \mathrm{g}\right)$ were not appreciably decreased from that of the powder $\left(11.6 \mathrm{~m}^{2} / \mathrm{g}\right)$; however, the surface area decreased to $9.2 \mathrm{~m}^{3} / \mathrm{gm}$ upon heating to $2400^{\circ} \mathrm{C}$ and to $8.5 \mathrm{~m}^{2} / \mathrm{g}$ after $2800^{\circ} \mathrm{C}$. The specific surface area ${ }^{(a)}$ of compacts, produced by Rakaszawski et al., (22) increased from $1.8 \mathrm{~m}^{2} / \mathrm{g}$ (for the powder) to about $2.3 \mathrm{~m}^{2} / \mathrm{g}$ when the powder samples were compacted, at $690 \mathrm{MPa}$, to a density of about $2.13 \mathrm{Mg} / \mathrm{m}^{3}$; the authors concluded that this increase probably resulted from breakage of graphite particles during compaction. They used Grade $S P-1,(b)$ a purified natural flake powder ( 65 to $70 \%$ under $75 \mu \mathrm{m}$ ), that was reported to have been heat treated to $3000^{\circ} \mathrm{C}$.

Wirtz did not furnish many details; but, the natural flake had been chemically purified at 800 to $1000^{\circ} \mathrm{C}$ prior to crushing, and he noted that compaction of the graphite was "successful only with material of a certain chemical history." Rusinko and Walker used a commercially-available "micron-sized" powder, evidently in the "as-received" state; but, their compacts were of lower density and lower strength, even when compressed to much higher pressures than those reported by Wirtz.

Frechette et al. (23) obtained $2.86 \mathrm{~cm}$ diameter by $1 \mathrm{~cm}$ thick compacts with densities to $2.06 \mathrm{Mg} / \mathrm{m}^{3}$ at a pressure of $550 \mathrm{MPa}$; the natural Ceylon flake was wet-chemically purified after milling to -200 mesh $(74 \mu \mathrm{m})$. Laminated specimens were produced unless the powder was mixed with either alcohol or ether to form a paste which was then dried in the mold before pressing. A density of $2.08 \mathrm{Mg} / \mathrm{m}^{3}$ was obtained for compacts of Ceylon flake oxidized to $9 \%$ "graphitic oxide." However, on heating of the compacts, decomposition of the oxide occurred and densities were reduced without any appreciable dimensional change.

\section{ART IFICIAL GRAPHITE COMPACTS}

Frechette also reported that bonding of -200 mesh powder, made by grinding an electrode graphite, was achieved only after oxidation of the powder in Brodie's

(a) determined by adsorption of $\mathrm{N}_{2}$ at $196^{\circ} \mathrm{C}$.

(b) National Special Spectroscopic Graphite Powder, Grade SP-1, produced by the National Carbon Company (now the Carbon Products Division of Union Carbide Corporation). 
Reagent (potassium chlorate in fuming nitric acid). The highest density (1.91 Mg/ $\mathrm{m}^{2}$ ) was obtained by pressing (at $410 \mathrm{MPa}$ ) powders which had been converted to $20 \%$ "graphitic oxide."

Mrozowski ${ }^{(24)}$ described the production of compacts made from carbon blacks and micronized coke powders. These samples were made by heating the compacted powder in the mold (but not under pressure) during heating to $900-1000^{\circ} \mathrm{C}$. Using a powder made' from a coke which was calcined to $1200^{\circ} \mathrm{C}$ and micronized in air, solid compacts were obtained only if the powder had not been heated above $600^{\circ} \mathrm{C}$ after micronization. Mrozowski also speculated ${ }^{(24)}$ that solid compacts might be obtained from coke powders micronized in vacuum, even without baking.

May $(25,26)$ briefly reviewed some of the previous work and reported the results of a fairly extensive investigation of artificial graphite compacts. Using graphite ground to finer than $25 \mu \mathrm{m}$ (50\% of the particles were less than $10 \mu \mathrm{m})$, compacts with a density of $1.95 \mathrm{Mg} / \mathrm{m}^{3}$ and a compressive strength of $20 \mathrm{MPa}$ were produced at a pressure of $1240 \mathrm{MPa}$. However, coherent compacts could not be obtained, when only $50 \%$ of the powder was less than $12.6 \mu \mathrm{m}$ (maximum size of this powder was not reported).

In general, May observed ${ }^{(25)}$ a correlation between compressive strength and density; also, it was observed that the strength and density were inversely related to the amount of expansion which occurred when the pressing load was removed from the compact. The final density and compressive strength was lowered by use of other than freshly ground graphite. At a compaction pressure of $930 \mathrm{MPa}$, compressive strengths of about $28 \mathrm{MPa}$ and densities of about $2.02 \mathrm{Mg} / \mathrm{m}^{3}$ were obtained for powders with less than $1 \%$ moisture content; but, compressive strengths were reduced to about $16 \mathrm{MPa}$ and densities to about $1.94 \mathrm{Mg} / \mathrm{m}^{3}$ for powders with $3 \%$ moisture content. It should be noted, however, that powders used in this study had been allowed to adsorb more than 4 weight percent of moisture and then were desiccated to reduce the moisture content.

May also noted that a -300 mesh $(53 \mu \mathrm{m})$ graphite which had been oxidized in Brodie's Reagent compacted "quite readily to give high density, strong compacts. However, this powder also showed a decrease in compacting properties on standing in moist atmospheres." 
Savage $(27,28)$ produced graphite "wear dust"(a) with a specific surface area (as measured by $\mathrm{N}_{2}$ adsorption) of $435 \mathrm{~m}^{2} / \mathrm{g}$, which is of the same magnitude as that of activated carbons. However, the wear dust had a chemically-active surface area (as measured by $\mathrm{H}_{2}$ chemisorption) of $5.16 \mathrm{~m}^{2} / \mathrm{g}$, which is on the order of $10^{5}$ times that of a typical activated carbon with the same specific surface area. This wear dust can remove $\mathrm{H}_{2}$ from a moderate vacuum at room temperature. It also chemisorbed $\mathrm{N}_{2}, \mathrm{CH}_{4}$, and $\mathrm{CO}$; the volumes chemisorbed at standard temperature and pressure were, respectively, $9 \%$, about $50 \%$, and "somewhat" more than the volume $\left(2 \mathrm{~cm}^{3} / g\right)$ of $\mathrm{H}_{2}$ chemisorbed.

Livey et al., (29) investigated the effect of particle size (milling time) on the density and strength of compacts prepared from "pile-quality graphite." They started with a powder machined from a graphite rod. Fifty-two weight percent of the particles in the "as-received" powders were retained on a BSS 72 mesh $(211 \mu \mathrm{m})$ screen. Under pressure up to $1080 \mathrm{MPa}$, the as-received powder could not be compacted. ${ }^{(b)}$ A series of 10 powders were prepared by milling for lengths of time between 9 and 90 hours. After 90 hours, 56 weight percent of the particles were reduced to less than $10 \mu \mathrm{m}$, as determined by light-extinction sedimentometry. The surface area (by $\mathrm{N}_{2}$ adsorption) was increased from about $6 \mathrm{~m}^{2} / g$ (equivalent to a mean particle diameter of about $0.2 \mu \mathrm{m}$ ) to $37 \mathrm{~m}^{2} / \mathrm{g}$ (equivalent to about $0.07 \mu \mathrm{m}$ mean diameter; i.e., close to the crystallite size); this surface area is still much less than the $435 \mathrm{~m}^{2} / \mathrm{g}$ reported by Savage and Brown ${ }^{(28)}$ for their graphite "wear dust." When the compacts were ejected from the die, a small expansion (about $2.5 \%$ with the 27 hour powder and about $1.0 \%$ with the 90 hour powder) occurred. Compacts greater than $25 \mathrm{~mm}$ diameter tended to shear during ejection from a simple die body; however, with a sleeved die, compacts were produced with a diameter of $38 \mathrm{~mm}$ and $1.95 \mathrm{Mg} / \mathrm{m}^{3}$ density. Ring-shaped compacts, up to $38 \mathrm{~mm}$ outside diameter and $32 \mathrm{~mm}$ inside diameter, were also produced in simple dies. Samples of hydrostatically compacted powders were produced at $310 \mathrm{MPa}$; densities up to $1.89 \mathrm{Mg} / \mathrm{m}^{3}$ were obtained on tubes and cylinders up to $130 \mathrm{~mm}$ long and with diameters of 12 to $18 \mathrm{~mm}$.

(a) "Wear dust" is the fine powder produced by rubbing a graphite surface against another surface.

(b) However, a commercial ultrafine graphite powder (Acheson: Dag 621) compacted very well in the "as-received" condition. 
The 90-hour powder yielded compacts of $1.92 \mathrm{Mg} / \mathrm{m}^{3}$ at $460 \mathrm{MPa}$, and $1.98 \mathrm{Mg} / \mathrm{m}^{3}$ at $1080 \mathrm{MPa}$; the latter samples had a helium density of $2.17 \mathrm{Mg} / \mathrm{m}^{3}$ and a compressive strength of $15.6 \mathrm{MPa}$. However, powders annealed at $1000^{\circ} \mathrm{C}$ in vacuo prior to compaction, or hot-compacted at $800^{\circ} \mathrm{C}$ in vacuo, did not cohere when pressed at $150 \mathrm{MPa}$; they crumbled when ejected from the die at room temperature. The compacting properties could be partially restored by oxidizing in $\mathrm{HNO}_{3}$ at $80^{\circ} \mathrm{C}$ or by regrinding the annealed powder in argon; however, the compacts were of lower density than that obtained with the freshly ground powder.

The compacts had very small pores $(\leq 0.35 \mu \mathrm{m})$ and very low permeability to gases ( $1 / 3$ to $1 / 100$ of the permeability of Morgan Crucible Company grade EY-9, which is a dense, low-porosity graphite with small and uniform pores). The room-temperature permeability coefficients of a sample compacted to $1.96 \mathrm{Mg} / \mathrm{m}^{3}$ were $B_{0}=0.45 \times 10^{14} \mathrm{~cm}^{2}$ and $K_{0}=2.17 \times 10^{9} \mathrm{~cm}^{2}$. It appears that compacts could approach, or equal, the low permeability obtained after impregnations of EY-9 with furfuryl alcohol. $(30,31)$

Other powders were annealed for 3 hours at $1000^{\circ} \mathrm{C}$ in a vacuum of $13 \mathrm{MPa}$ $\left(10^{-4} \mathrm{~mm} \mathrm{Hg}\right)$, exposed to various atmospheres and then pressed at $230 \mathrm{MPa}$; Dag 621 powder when annealed, exposed (to argon, air, hydrogen, or water vapor), and pressed expanded to about $170 \%$ of its compressed height when the pressure was released (the "as-received" Dag 621 expanded only 23\%, and the resultant pellet had a density of $1.8 \mathrm{Mg} / \mathrm{m}^{3}$ ); the 90 hour powder, annealed and exposed to air, expanded about the same as the annealed Dag 621 powder. A natural flake (annealed and exposed to air) expanded only about $8 \%$ and had a density of about $2.2 \mathrm{Mg} / \mathrm{m}^{3}$; however, the compact was "extremely friable" compared to compacts prepared using unannealed flake.

de Vere et al., (32) investigated the effect of multiple compaction, shear deformation during compaction, and annealing after compaction on the density and bending strength of compacted powders. Artificial graphite, ground to a "mean volume diameter" of $12 \mu \mathrm{m}$, was used in their investigations; - 300 BSS mesh $(53 \mu \mathrm{m})$ natural Ceylon powder was also used in some of their studies. Multiple compaction at $770 \mathrm{MPa}$ yielded compacts with a density of $2.20 \mathrm{Mg} / \mathrm{m}^{3}$ with a bending strength of $15.2 \mathrm{MPa}$ for the natural graphite, and a density of $2.06 \mathrm{Mg} / \mathrm{m}^{3}$ with a bending strength of $15.9 \mathrm{MPa}$ for the artificial graphite powders. Annealing the artificial graphite compacts at $800^{\circ} \mathrm{C}$ reduced the 
density by as much as $3.2 \%$ but the strength increased by as much as $30 \%$. Using the Young's modulus and expansion during annealing, for a natural graphite compacted at $310 \mathrm{MPa}$, they calculated that the expansion corresponded to a stress relief of $50 \mathrm{MPa}$, "which is considerably higher than the strength of the compact."

Artificial graphite powders ground for longer times (smaller mean particle size and larger surface area) produced compacts with lower densities and higher bending strengths. The finest powder (mean volume diameter of $3.6 \mu \mathrm{m}$ ) produced compacts which were "16\% less dense and 30\% stronger than those produced from the coarsest powder" (mean volume diameter of $12.3 \mu \mathrm{m}$ ). A much larger reduction in density (23\%) was observed for compacts of natural graphite powder, but particle sizes or strengths are not reported.

The data of de Vere et al., on the artificial graphite powders, compacted at $310 \mathrm{MPa}$, are well represented by the empirical relationship:

$$
S=5.47 A^{5 / 2}
$$

where: $\quad S=$ bending strength in $\mathrm{MPa}$, and

$A=$ specific surface area in $\mathrm{m}^{2} / \mathrm{g}$.

The relationship between bending strength and density changes, produced by multiple compaction or shear deformation, are well represented by the expression:

$$
S=S_{0}\left(\frac{P_{0}}{P}-1\right)
$$

where: $S$ is the bending strength in $\mathrm{MPa}$,

$P$ is the porosity, and

$P_{0}$ and $S_{0}$ are constants which depend on the material and particle size, for the artificial graphite compacts, $S_{0}=2.80$ and $P_{0}=0.5$.

\section{SUMMARY OF COMPACT PROPERTIES}

A brief description of the compacts and their properties are given in Tables 1 and 2; it should be noted that all powders had been contaminated, to a lesser or greater degree, by oxygen, nitrogen and water vapor. These adsorbed gases will reduce both the strength and density of the compact. 
TABLE 1. Natural Graphite Compacts

\begin{tabular}{|c|c|c|c|c|c|c|c|}
\hline Reference & $\begin{array}{l}\text { Ref. } \\
\text { No. }\end{array}$ & Description & $\begin{array}{l}\text { Forming } \\
\text { Pressure } \\
\text { (MPa) } \\
\end{array}$ & $\begin{array}{l}\text { Density } \\
\left(\mathrm{Mg} / \mathrm{m}^{3}\right)\end{array}$ & 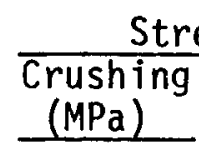 & $\begin{array}{l}\text { igth } \\
\text { Flexural } \\
\text { (MPa) }\end{array}$ & $\begin{array}{l}\text { Therma l } \\
\text { cond. } \\
(\mathrm{W} / \mathrm{m} \cdot \mathrm{K})\end{array}$ \\
\hline Wirtz & 20 & Purified, German(a) & 290 & 2.07 & 17.7 & -- & 126 \\
\hline \multirow[t]{3}{*}{ Rusinko, Walker } & \multirow[t]{3}{*}{21} & \multirow[t]{3}{*}{ Dixon's Type $200-10^{(b)}$} & 80 & 1.61 & 5.4 & -- & -- \\
\hline & & & 220 & 1.83 & 9.5 & -- & - \\
\hline & & & 860 & 1.99 & 12.8 & -- & -- \\
\hline Rakaszawski et al. & . 22 & $\begin{array}{l}\mathrm{SP}-1, \text { (b) }^{(b 5} \text { to } 75 \% \\
\text { minus } 74 \mu \mathrm{m}\end{array}$ & 690 & 2.13 & -- & -- & -- \\
\hline \multirow[t]{4}{*}{ Frechette et al. } & \multirow[t]{4}{*}{23} & \multirow[t]{4}{*}{ Purified Ceylon, $-74 \mu \mathrm{m}(\mathrm{c})$} & 140 & 1.98 & -- & -- & -- \\
\hline & & & 280 & 2.03 & -- & -- & -- \\
\hline & & & 410 & 2.05 & -- & -- & -- \\
\hline & & & 550 & 2.06 & -- & -- & -- \\
\hline \multirow[t]{4}{*}{ de Vere et al. } & \multirow[t]{4}{*}{32} & \multirow[t]{4}{*}{ Ceylon, $-53 \mu \mathrm{m}^{(\mathrm{c})}$} & $310^{(d)}$ & 2.14 & & 8.3 & -- \\
\hline & & & $770^{(d)}$ & 2.15 & -- & 9.7 & -- \\
\hline & & & $310^{(e)}$ & 2.18 & -- & 12.1 & -- \\
\hline & & & $770^{(e)}$ & 2.20 & -- & 15.2 & -- \\
\hline
\end{tabular}

\footnotetext{
(a) Compacts thermally hardened at 800 to $900^{\circ} \mathrm{C}$

(b) As-received, commercial powder

(c) Maximum particle size

(d) Flat-press compaction

(e) Multiple compaction
} 
TABLE 2. Artificial Graphite Compacts

\begin{tabular}{|c|c|c|c|c|c|c|c|}
\hline Reference & $\begin{array}{l}\text { Ref. } \\
\text { No. }\end{array}$ & Notes & $\begin{array}{l}\text { Max. } \\
\text { Part. } \\
\text { size } \\
\text { (um) } \\
\end{array}$ & $\begin{array}{l}\text { Forming } \\
\text { Pressure } \\
\text { (MPa) } \\
\end{array}$ & $\begin{array}{l}\text { Density } \\
\left(\mathrm{Mg} / \mathrm{m}^{3}\right)\end{array}$ & $\begin{array}{l}\frac{\text { Stre }}{\text { Crushing }} \\
\text { (MPa) }\end{array}$ & $\begin{array}{l}\text { ggth } \\
\text { Flexural } \\
(\mathrm{MPa})\end{array}$ \\
\hline Mrozowski et al. & 24 & $\operatorname{air}(a)$ & -- & -- & -- & $\sim 21.0^{(b)}$ & \\
\hline \multirow[t]{7}{*}{ May } & \multirow[t]{7}{*}{25} & -- & $25^{(c)}$ & 310 & 1.76 & 6.3 & \\
\hline & & -- & $25^{(c)}$ & 620 & 1.91 & 14.8 & \\
\hline & & -- & $25^{(c)}$ & 930 & 1.93 & 18.6 & \\
\hline & & -- & $25^{(c)}$ & 1240 & 1.95 & 20.2 & \\
\hline & & (d) & $25^{(c)}$ & 930 & 2.01 & 26.2 & \\
\hline & & (e) & $25^{(c)}$ & 930 & 1.98 & 21.4 & \\
\hline & & $(f)$ & $25^{(c)}$ & 930 & 1.95 & 16.5 & \\
\hline \multirow[t]{3}{*}{ Livey et al. } & \multirow[t]{3}{*}{29} & & $40^{(g)}$ & $310^{(h)}$ & 1.89 & 10.3 & \\
\hline & & & & 460 & 1.92 & & \\
\hline & & & & 1080 & 1.98 & 16.0 & \\
\hline \multirow[t]{5}{*}{ de Vere et al. } & \multirow[t]{5}{*}{32} & \multirow[t]{5}{*}{--} & (i) & $310^{(j)}$ & 1.89 & -- & 6.2 \\
\hline & & & (i) & $700^{(j)}$ & 1.96 & -- & 9.0 \\
\hline & & & (i) & $310^{(k)}$ & 2.00 & -- & 10.3 \\
\hline & & & (i) & $700^{(k)}$ & 2.06 & -- & 15.9 \\
\hline & & & (i) & $310^{(1)}$ & 2.06 & -- & 12.4 \\
\hline
\end{tabular}

\footnotetext{
(a) Ground in air

(b) Strength is for carbon black compacts after heating to $900-1000^{\circ} \mathrm{C}$

(c) $50 \%$ less than $10 \mu \mathrm{m}$

(d) The powders had a residual moisture content of $1 \%$

(e) The powders had a residual moisture content of $2 \%$

(f) The powders had a residual moisture content of $3 \%$

(g) $56 \%$ less than $10 \mu \mathrm{m}$

(h) Hydrostatically compacted

(i) Mean particle diameter of $12 \mu \mathrm{m}$

(j) Flat press compaction

(k) Multiple compaction

(1) Shearbox compaction
} 


\section{MODIFICATION OF COMPACT PROPERTIES}

\section{INCORPORATION OF OTHER MATERIALS}

Livey et al. , ${ }^{(29)}$ produced good compacts, with up to $92.5 \%$ of theoretical densities, using mixtures of their most finely-milled graphite powder* and the -300 BSS mesh $(53 \mu \mathrm{m})$ fractions of $\mathrm{UO}_{2}, U$, and Th powders pressed at $1080 \mathrm{MPa}$. They also produced compacts from a mixture of $9 \mathrm{~g}$ uranium, $35 \mathrm{~g}$ thorium and $90 \mathrm{~g}$ graphite. Sleeve-shaped compacts ( $38 \mathrm{~mm}$ outside diameter and $32 \mathrm{~mm}$ inside diameter) up to $150 \mathrm{~mm}$ long were produced; however, sleeves longer than about $12 \mathrm{~mm}$ tended to distort when ejected from the simple die. Compacts with "satisfactory" strength were produced at pressures as low as $310 \mathrm{MPa}$. On heating to $1400-1500^{\circ} \mathrm{C}$ in argon, the metals reacted to form carbides, but the sleeves remained intact. At room-temperature, the thorium carbide readily reacts with water vapor in the air, causing the sleeves to crack and crumble to a powder.

Goeddel, Tully, and Meyer ${ }^{(33)}$ have shown that high-strength, low-permeability compacts can be prepared from mixtures of $\mathrm{ThO}_{2}, \mathrm{UO}_{2}$, graphite, and a very small amount of pitch-binder, by warm-pressing (at $1000^{\circ} \mathrm{C}$ or below) and sintering at higher temperatures $\left(1200\right.$ to $\left.2200^{\circ} \mathrm{C}\right)$. White and coworkers $(34-37)$ used the same general technique at even higher temperatures and have examined the effects of processing variables on the properties of the finished compact; one result of primary importance is that they demonstrated that a liquid-phase of $\mathrm{Mo}_{2} \mathrm{C}$ acts as a sintering aid, thereby reducing the time-temperature stress required to obtain a given strain (reduction in porosity). Matthews, Fischbach, and Jenkins ${ }^{(38)}$ examined the effects of Mo metal on the strength of natural Ceylon compacts and the effect of hot-working the compacts at temperatures above the molybdenum-carbon reaction temperature; they observed that addition of 50 weight percent of molybdenum powder increased the compressive strength by more than a factor of 3 . After heating to $1510^{\circ} \mathrm{C}$ (the lowest temperature investigated) and hot-working to $4.9 \%$ strain, the compressive strength of the 50 weight percent Mo compact was increased by about $50 \%$. Strength of the compacts was increased by increasing the hot-work temperature, increasing the

* See page 8 
strain during hot-working, and decreasing the size of the Mo particles. Compressive strengths of $142 \mathrm{MPa}$ were attained during this study; but, the processing was not optimized, and there is every indication that even higher strengths could be obtained.

Fitzer and Kegel ${ }^{(39)}$ reviewed the effect of various elements on catalyzing the graphitization process; they also reported the results of their extensive investigations using molten $\mathrm{VaC}, \mathrm{TiC}, \mathrm{ZrC}, \mathrm{Fe}$, and $\mathrm{Ni}$ as graphitization catalysts at temperatures between 2650 and $3000^{\circ} \mathrm{C}$. A glass-like carbon was rapidiy transformed (recrystallized) to a well-ordered graphite structure; a pyrolytic graphite reacted more slowly, and no reaction was observed between the melts and flakes of natural graphite.

Derbyshire, Presland, and Trimm ${ }^{(40)}$ showed that graphite could be recrystallized by nickel and cobalt at temperatures as low as $600^{\circ} \mathrm{C}$. Noda ${ }^{(41)}$ reviewed results of an extensive series of investigations which included the effect of various minerals on the high-pressure graphitization of carbons; in some cases, recrystallization was observed at $600^{\circ} \mathrm{C}$ under only $100 \mathrm{MPa}$ pressure.

Noda ${ }^{(14)}$ also noted that natural flake graphite has a $c_{0}$-spacing of $670.8 \mathrm{pm}$, whereas the $c_{0}$-spacing of "artificial" graphites are generally $671.8 \mathrm{pm}$ or larger, even after heating to $3600^{\circ} \mathrm{C}$ under $1.0 \mathrm{MPa}$ pressure. Transformation to the $670.8 \mathrm{pm}$ spacing was obtained by:

1) solidification of a carbon melt,

2) crystallization from carbonsaturated melts of metals, and

3) decomposition of carbides.

Mochida and co-workers ${ }^{(42-50)}$ have studied the effect of various catalysts on the carbonization and graphitization processes. They determined that the microstructure of cokes, obtained from the same precursor hydrocarbon, was highly dependent on the catalyst present during coking. Chromium oxide was the most effective graphitization catalyst which they examined, promoting graphitization at $1150^{\circ} \mathrm{C}$.

Sulfur and many sulfur compounds readily react ${ }^{(51-54)}$ with carbon blacks and other "disorganized carbons" to form C-S-C or C-S-S-C bonds. Puri ${ }^{(53)}$ has 
critically reviewed the literature and has noted that these sulfur-carbon complexes are very stable; they do not decompose when heated with concentrated $\mathrm{HNO}_{3}$ at $110^{\circ} \mathrm{C}$. Porosity and adsorption of water is also reduced by formation of the complexes, formed (for example) by heating with $\mathrm{CS}$, at $600^{\circ} \mathrm{C}$. Raskovic and Marinkovic ${ }^{(54)}$ have reported that treatment of $\mathrm{PAN}^{(\mathrm{a})^{2}}$ fibers with $\mathrm{SO}_{2}$ at 230 and $290^{\circ} \mathrm{C}$ during carbonization resulted in greatly improved mechanical properties (increased strength and elastic modulus) of the resultant carbon fibers.

Any metal which does not react with graphite, or which forms a carbide that cannot be hydrolyzed by water vapor should improve the strength and reduce the porosity of the compact. This subject is discussed in more detail in the following section.

\section{ELIMINATION OF POROSITY}

Impervious graphite has long been used in the chemical industry ${ }^{(55-57)}$ for applications where corrosion resistance is important. Fine-grained graphites with small pores (generally less than $5 \mu \mathrm{m}$ dia) are impregnated with synthetic resins which are then polymerized in place. Thermal conductivity remains essentially unchanged from that of the base stock, but strength can be increased by a factor of three or more; materials can be produced that are impervious, even to pressurized gases. For the present application, the primary concern would be the possible decomposition of the resin in the radiation field produced by the waste.

Pyrolysis of hydrocarbon after impregnation $(30,58-61)$ increases the strength and reduces permeability, but shrinkage and gas evolution re-introduces some porosity during pyrolysis. Pyrolysis of the impregnants under high-pressure reduces the gas evolution but does not completely eliminate the porosity. (62-64) Additions of sulfur $(65)$ has also been shown to significantly decrease gas evolution during pyrolysis.

Reduction of porosity near the surface can also be obtained by chemical vapor deposition of pyrolytic carbon $(56-69)$ or carbides. $(70,71)$ complexes with

(a) polyacrylonitrile 
sulfur can be formed by heating the compact with sulfur vapor, or sulfur compounds. (72-75) Carbon disulphide seems to form exceptionally stable complexes and reduces the pore radii, thus decreasing porosity.

Impregnation with molten metals or alloys $(76-78)$ is a very effective means of producing a completely impermeable material; strength and elastic moduli also increase dramatically. ${ }^{(78)}$ The increase in strength obtained with nonwetting metals or alloys is on the same order as that obtained by impregnation with polymers, and is independent of the alloy. If the metal wets (reacts with) the graphite the strength increase is larger, but it is still independent of the mechanical properties of metal. (78)

A considerable amount of work has been done in developing brazing alloys; ${ }^{(79-81)}$ these alloys, of course, wet the graphite. Melting temperature, fluidity and amount of reaction can be controlled (at least to some degree) by choice of alloy composition; extension of this technology to metal impregnant systems might greatly improve the overall performance of the impregnated compacts.

It should be noted that the porosity should not be estimated from the measured bulk density, using the theoretical density of a perfect graphite crystal $\left(2.26 \mathrm{Mg} / \mathrm{m}^{3}\right)^{(11)}$ as $100 \%$ density. Walker and Seeley ${ }^{(82)}$ have extensively investigated the degradation in crystal perfection produced by fine grinding of ceylon natural-flake graphite; their results, like those of Bobka for wear-dust, confirm that the $c_{0}$-spacing increases dramatically during reduction in the particle size. For example, $c_{0}$-spacings of $760 \mathrm{pm}$ (and larger) were produced by Walker and Seeley; this increase in $c_{0}$-spacing implies at least a $13 \%$ reduction in density (to $2.00 \mathrm{Mg} / \mathrm{m}^{3}$, or less) for $100 \%$ dense compacts made of these powders.

\section{COMPARISON WITH OTHER MATERIALS}

Gurwell ${ }^{(10)}$ has made an extensive review of possible matrix materials; specific materials were eliminated because of poor corrosion resistance, high cost, poor availability, or inability to fabricate at temperatures compatible 
with waste materials. A detailed comparison will not be undertaken here; however, some comparison is in order for this review.

- The corrosion rates of graphite in deionized water at $99^{\circ} \mathrm{C}$ and $250^{\circ} \mathrm{C}^{(84)}$ are "orders of magnitude less than any other material measured to date". (10)

- Thermal expansion coefficient (CTE) of graphite compacts will depend on many factors, such as particle size, crystallinity of the starting powder, compacting method, relative dimensions (height-to-diameter ratio) and compact density. The CTE can be expected to be quite anisotropic; for example, Livey et al. ${ }^{(29)}$ reported 3.6 and $18.9 \times$ $10^{-6} /{ }^{\circ} \mathrm{C}(\mathrm{a})$ (for the $1.95 \mathrm{Mg} / \mathrm{m}^{3}$ compacts from their 90-hour powder); de Vere et al., ${ }^{(32)}$ reported 1 and $19 \times 10^{-6} /{ }^{\circ} \mathrm{C}(\mathrm{a})$ for $2.12 \mathrm{Mg} / \mathrm{m}^{3}$ compacts made from $-53 \mu \mathrm{m}$ natural flake versus 3.2 and $11 \times 10^{-6(a)}$ for more finely ground natural flake. In general, this anistropy should be of benefit in that 1) the low CTE, relative to that of most canister materials, will tend to maintain good mechanical contact between the canister and compact, and 2) the high CTE in the axial direction will maintain mechanical contact with the waste bodies.

- Thermal conductivity can also be expected to be very anistropic; this anisotropy can be of benefit because an axially compacted cylinder will have a high conductivity in the radial direction. Table 3 compares the thermal conductivities of several graphite materials with those of other candidate materials.

- A strong and ductile material is preferable; but, no real criteria have been established. (10) Until the properties of the canister (and/or overpack materials) are established, structural integrity during "normal" handling should be considered as the minimum requirement. Graphite is a "semi-brittle" material, (88) which is able to withstand fairly large nonelastic, as well as elastic, deformations without fracturing; this property (unique combination of properties) is extensively utilized by the aerospace industry (see, for example; references 89 to 94 , incl.)

(a) CTE measured perpendicular and parallel, respectively, to the pressing direction. 
TABLE 3. Comparison of Thermal Conductivities

Material

Pyrolytic Graphite, (PG)

annealed at $3200^{\circ} \mathrm{C}$

ZTA ${ }^{\text {(b) }}$

$\operatorname{TSX}(d)$

PGA (e)

Cast $\mathrm{Al}-12 \% \mathrm{Si}$

Cast $\mathrm{Cu}-\mathrm{Be}$

HIP Cu- $10 \% \mathrm{Ni}$

HIP Titanium

Cast $\mathrm{Al}_{2} \mathrm{O}_{3}-6 \%$ CaO

Borosilicate Glass

Polymers

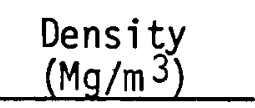

2.25

$1.95 / 1.92^{(c)}$

$1.71 \pm 0.03$

$1.70 / 1.69^{(c)}$

2.7

8.1

8.9

4.5

2.7

2.2
Room-Temperature Conductivity

$(\mathrm{W} / \mathrm{m} \cdot \mathrm{K})$ Ref. $1840 / 6.2^{(a)} \quad 85$

$187 / 58$

$222 / 114$

$164 / 97$

120

(a) Parallel/transverse to the plane in which the crystallite basil planes are oriented.

(b) A hot-worked graphite available from Union Carbide Corp.

(c) Densities for the thermal conductivity samples.

(d) Nuclear grade graphite produced by National Carbon Co.

(e) The standard British moderator graphite, produced by British Acheson Electrodes, Ltd.

(f) "Typical" value.

- Graphite (carbon) is non-toxic and at ordinary temperatures it is one of the most inert elements; ${ }^{(12)}$ if, however, it is ground to an extremely fine powder (much finer than the optimum size for this application), it can be pyrophoric on initial exposure to air. $(82,83)$

- As can be seen from the cost and availability data, shown in Table 4, natural flake graphite is much less expensive than most of the metals. Graphite particles ( $\$ 2100$ per cubic meter) and petroleum coke particles, which can be used to produce graphite particles, are much less expensive than any of the potential metal matrix materials. 
TABLE 4. Cost and Availability

Production

Import

\begin{tabular}{|c|c|c|c|c|c|c|c|}
\hline \multirow[b]{2}{*}{ Material } & \multirow{2}{*}{$\frac{\cos t}{(\$ / \mathrm{kg})}$} & \multirow{2}{*}{$\frac{\text { Density }}{\left(\mathrm{Mg} / \mathrm{m}^{3}\right)}$} & \multirow{2}{*}{$\frac{\text { Cost }}{\left(\mathrm{k} \$ / \mathrm{m}^{3}\right)}$} & \multicolumn{2}{|c|}{ Primary } & \multirow{2}{*}{$\frac{\frac{\text { Secondary }}{(\%)}}{}$} & \multirow{2}{*}{$\frac{\text { Reliance }^{(a)}}{(\%)}$} \\
\hline & & & & $(\mathrm{Tg})$ & $\left(\mathrm{hm}^{3}\right)$ & & \\
\hline $\begin{array}{l}\text { Natural } \\
\text { flake }\end{array}$ & $1.83^{(b)}$ & 2.26 & 4.14 & -- & -- & -- & -- \\
\hline $\begin{array}{l}\text { Graphite } \\
\text { particles }\end{array}$ & $0.93^{(c)}$ & 2.26 & 2.10 & -- & -- & -- & -- \\
\hline $\begin{array}{l}\text { Coke } \\
\text { particles }\end{array}$ & $0.45^{(d)}$ & 2.26 & 1.02 & -- & -- & -- & -- \\
\hline $\begin{array}{l}\text { Formed } \\
\text { graphite }\end{array}$ & $2.42^{(e)}$ & 2.26 & 5.47 & -- & -- & -- & -- \\
\hline Aluminum & 1.32 & 2.70 & 3.56 & 4.56 & 1.67 & 31 & 8 \\
\hline Copper & 2.05 & 8.92 & 18.29 & 1.56 & 0.175 & 94 & 13 \\
\hline Lead & 1.16 & 11.34 & 13.15 & 0.570 & 0.050 & 133 & 8 \\
\hline Nickel & $6.60^{(f)}$ & 8.90 & 58.74 & 0.034 & 0.0036 & 125 & 77 \\
\hline Steel & $1.83^{(g)}$ & 7.86 & 14.41 & $1.77^{(h)}$ & 0.225 & $74^{(i)}$ & $11^{(i)}$ \\
\hline Titanium & $8.76^{(j)}$ & 4.5 & 39.42 & $0.021^{(k)}$ & 0.0048 & 78 & 12 \\
\hline
\end{tabular}

(a) The net import reliance ${ }^{(95)}=$ (imports - exports + adjustments for changes in government and industry stockpiles)/apparent consumption. Apparent consumption $(95)=$ domestic primary metal production + recovery from old scrap + net import.

(b) Superior Graphite Co., No. 1 Flake; in large lots.

(c) Great Lakes Carbon Corp., Grade 1012; one or more $30 \mathrm{~kg}$ bags.

(d) Great Lakes Carbon Corp., Grade 3009; $22.7 \mathrm{Mg}$, or more, per order.

(e) Great Lakes Carbon Corp., Grade HC; 0.35 to $0.45 \mathrm{~m}$ diameter and $1.83 \mathrm{~m}$ long.

(f) Second-half of 1979.

(g) Cost was estimated from the Iron Age composite for 1979 for steel and cast iron, multiplied by the average price ratio (4.16) for stainless steel forgings/all steel for 1977 (p. 278 of ref. 96).

(h) 1978 production (p. 179 of ref. 96).

(i) Total for all iron and steel.

(j) Yearend price (1979) for sponge.

(k) Installed capacity; production not reported. 
Except where indicated, the cost shown in Table 4 is the average price per kilogram during 1979. (95) Based on the estimates by Gurwel1, (10) the demand for matrix material could be as high as $0.0014 \mathrm{hm}^{3}$ (1400 cubic meters) per year by the year 2000 .

Domestic production of natural graphite is insignificant compared to that imported; about $0.0022 \mathrm{hm}^{3}$ of natural flake was imported from Madagascar in 1979, mostly for use in crucibles and other refractory articles. Domestic production of petroleum coke is not known; but, about half of the coke is burned as fuel and most of the remainder is used for production of electrodes. (12) The aluminum industry is a major consumer; on the average, about $0.60 \mathrm{~m}^{3}$ of electrodes are consumed to produce one cubic meter of aluminum. (12) Thus, the annual production of petroleum coke probably exceeds $2.0 \mathrm{hm}^{3}$.

Gurwel1 ${ }^{(10)}$ notes that the $\mathrm{Cu} / \mathrm{Ni}$ alloys $(70 / 30$ or $90 / 10)$ show much promise for use as a matrix material. However, it should be noted that most of our nickel is imported and only about $30 \%$ of the primary production, shown in Table 4 is from domestic ores; the remainder is from imported matte. Thus, even the $90 / 10$ alloy could require more than 10 percent of domestic primary production.

Chromium is an important constituent of stainless steels. The USA is $90 \%$ dependent on imported chromium, and the remaining $10 \%$ is derived from recycled scrap. Moreover, if a high-chrome, high-nickel stainless steel is used in order to improve corrosion resistance of the matrix (for example, Type 310 is $25 \% \mathrm{Cr}$ and $20 \% \mathrm{Ni}$ ) both the $\mathrm{Cr}$ and $\mathrm{Ni}$ resources would be rapidly depleted.

Gurwel1 ${ }^{(10)}$ recommended that titanium be the leading metal matrix material. About 60 percent of titanium production is consumed by the aerospace industry; there is essentially no substitute for titanium in these applications. Even with the rapid expansion in titanium production which is projected to occur, use of $\mathrm{Ti}$ as a matrix material would still consume a significant fraction of production capacity in the year 2000. 


\section{CONCLUSIONS AND RECOMMENDATIONS}

1) A matrix formed by cold compaction of graphite powders offers several advantages over metallic matrix materials. These advantages include a) exceptional corrosion resistance, b) high thermal conductivity, c) an advantageous anisotrophy in both themal conductivity and themal expansion, d) almost unlimited availability, and 3) very low cost.

2) Additional work needs to be done to develop the concept and to provide a detailed comparison with other potential matrix materials. Specifically,

a) compacts should be manufactured from powders which have not been exposed to chemically active gasses, b) the effects of raw materials and processing variables should be investigated in order to optimize physical properties, and c) conceptual work needs to be done to optimize a multi-barrier protective containment package which takes advantage of graphite's unique properties.

3) In order to obtain coherent ccld-compacts, artificial graphites must be ground to a much finer powder than is required for natural flake; however, at a given compaction pressure, the cold-compacted artificial graphite powders possess higher strength than do the natural graphite compacts.

4) Permeability, rather than porosity, should be directly measured for air, water, and water vapor. Grinding of graphite powders degrades their crystal perfection; thus, bulk density is not a valid measure of the porosity or permeability of the compacts.

5) A waste matrix formed by cold-compaction of finely-milled artificial graphite powders around radioactive waste forms, such as marbles or pellets, offers several advantages over metallic matrix materials; for example:

- Lower cost per unit volume.

- Less depletion of strategic materials.

- Increased corrosion resistance.

- Higher themal conductivity than that of aluminum and possibly above that of copper. 
6) To obtain maximum density and strength of the cold-compacted matrix:

- The graphite should be outgassed prior to milling in vacuum (preferably) or in an inert gas (not $\mathrm{N}_{2}$ ).

- Subsequent processing steps should be carried out in vacuum or an inert atmosphere.

- Finely ground powders (of metals, the waste, or other ceramics) should be blended with the graphite powder.

- The compact should be annealed (nominally to $800-1000^{\circ} \mathrm{C}$ ), but the annealing temperature should be below that at which gaseous reaction products $(a)$ are produced.

7) An additional increase in density and strength will result if:

- The annealing is done under pressure.

- The incorporated powders melt during annealing, but evolution of gases should be avoided.

- The finished compact is impregnated, e.g., with a resin, a metal, or sulfur.

(a) If calcined waste powders are used, it may be necessary to increase the calcining temperature to avoid a direct reaction between the waste and the graphite. 


\section{REFERENCES}

1. J. E. Mendel (editor), Annual Report on the Characteristics of High-Level Waste G1asses, BNWL-2252, Pacific Northwest Laboratory, Richland, WA 99352, June 1977.

2. W. A. Ross (editor), Annual Report on the Characterization of High-Level Waste Glasses, PNL-2625, Pacific Northwest Laboratory, Richland, WA 99352, June 1978.

3. W. A. Ross and J. E. Mendel (editors), Annual Report on the Development and Characterization of Solidified Forms of High-Level Wastes, PNL-3060, Pacific Northwest Laboratory, Richland, WA 99352, December 1979.

4. J. M. Rusin et a1., Multibarrier Waste Forms, Part I: Development, PNL-2668-1, Pacific Northwest Laboratory, Richland, WA 99352, September 1978.

5. J. M. Rusin, W. J. Gray, and J. W. Wa1d, Mu1tibarrier Waste Forms, Part II: Characterization and Evaluation, PNL-2668-2, Pacific Northwest Laboratory, Richland, WA 99352, August 1979.

6. R. 0. Lokken, Mu1tibarrier Waste Forms, Part III: Process Considerations, PNL-2668-3, Pacific Northwest Laboratory, Richland, WA 99352, October 1979.

7. Radioactive Waste Processing and Disposal, NUREG-0643, Technical Information Center, Oak Ridge Nationa1 Laboratory, Oak Ridge, TN 37830, January 1980.

8. Radioactive Waste Processing and Disposal, NUREG-0644, Technical Information Center, Oak Ridge National Laboratory, Oak Ridge, TN 37830, January 1980.

9. R. L. Treat, "A Comparative Study of Alternative High-Level Waste Solidification Processes," PNL-SA-8280, Pacific Northwest Laboratory, Rich1and, WA 99352, February 1980; to be publ ished in Proc. Waste Management '80, Tucson, AZ, March 10-13, 1980.

10. W. E. Gurwe11, A Survey of Matrix Materials for Sol idified Radioactive High-Level Waste, PNL-3512, Pacific Northwest Laboratory, Richland, WA 99352, December 1980.

11. R. E. Nightingale, "Various Forms of Carbon," Fundamentals of Refractory Compounds, Plenum Press, pp. 203-228, 1968.

12. Charles L. Mante11, Carbon and Graphite Handbook, Interscience Publishers, New York, 1968.

13. Rodney N. Hader, B. W. Gamson, and Bruce L. Bailey, "Graphite Electrodes," Ind. Eng. Chem., 46, 2, 1954. 
14. L. D. Loch and J. A. S1yh, "The Technology and Fabrication of Graphite," Nucl. Eng., Part I, Chem. Eng. Prog. Symp. Ser. No. 11, pp. 39-44, 1954.

15. H. Boeder and E. Fitzer, "Densification of Carbon and Graphite Artifacts by Hot Working at Temperatures Above $2500^{\circ} \mathrm{C}, "$ High Temperatures-High Pressures, 2, 325, 1970.

16. Donald C. Carmichael, P. Darrell Ownby, and Edwin S. Hodge, Hot Isostatic Compaction of Graphite, BMI-1746, Battelle Memorial Institute, Columbus, OH, October 1965.

17. W. C. Chard and D. E. Niesz, "The Development of Polycrystalline BinderFree Graphites, " 11th Biennial Conference on Carbon, CONF-730601, pp. 71-73, June 1973 .

18. K. Kobayashi, I. Ogawa, H. Honda, and Y. Matsushita, "Graphitized High Density Carbon with No Pitch Binder," 12th Biennial Conference on Carbon, CONF-750410, University of Pittsburgh, pp. 247-248, July 1975.

19. K. Kobayashi, I. Ogawa, and H. Honda, "Transformation to Hard-Type Carbon Sol ids from Petroleum Coke Powder by Grinding, " Carbon, 16, 212, 1978.

20. K. Wirtz, "Production and Neutron Absorption of Nuclear Graphite," Proceedings of the International Conference on the Peaceful Uses of Atomic Energy, U.N., New York, Vol. 8, pp. 496-499, 1956.

21. F. Rusinko, Jr., and P. L. Walker, Jr., "Properties of Molded Ceylon Natural Graphite," Proceedings of the Fourth Conference on Carbon, Pergamon Press, London, pp. 751-762, 1960.

22. J. F. Rakaszawski, F. Rusinko, Jr., and P. L. Walker, Jr., "Catalysis of the Carbon-Carbon Dioxide Reaction by Iron," Proceedings of the Fifth Conference on Carben, Pergamon Press, London, Vol. 2, pp. 243-250.

23. V. D. Frechette, John Hay, and Yng Tao, "Experiments on the Compaction of Graphite," Proceedings of the First and Second Conferences on Carbon, Waverly Press, Baltimore, pp. 189-194, 1956.

24. S. Mrozowski, A. Chaberski, E. E. Loebner, and H. T. Pinnick, "Electronic Properties of Heat-Treated Carbon Blacks," Proceedings of the Third Carbon Conference, Pergamon Press, London, pp. 211-222, 1959. (See also S. Mrozowski, U.S. Patent No. 2,682,686, U.S. Patent Office, Washington, DC, 1954.)

25. J. R. May, "Compaction of Artificial Graphite," Proceedings of the Fifth Conference on Carbon, Pergamon Press, London, Vol. 1, pp. 611-624, 1962.

26. J. R. May and R. K. Warner, "Fine Grinding of Artificial Graphite," Proceedings of the Fourth Conference on Carbon, Pergamon Press, London, pp. 741-750, 1960 . 
27. R. H. Savage, "Graphite Lubrication," J. Appl. Phys., 19, 1, 1948.

28. R. H. Savage and C. Brown, "Chemical and Physical Adsorption of Gases on Carbon Dust," J. Am. Chem. Soc., 70, 2362, 1948.

29. D. T. Livey, I. Denton, N. Brett, and J. Williams, "The Compacting of Graphite and Graphite/Uranium/Thorium Mixtures," Powder Metall., No. 5, $430,1960$.

30. L. W. Graham, W. Watt, W. Johnson, P. A. P. Arragon, and M. S. T. Price, "The Development of Low Permeability Graphite for the Dragon Reactor Experiment," Proceedings of the Fifth Conference on Carbon, Pergamon Press, New York, Vol. 2, pp. 387-404, 1963.

31. T. R. Jenkins and F. Roberts, "Gas Permeability Studies on Some Artificial Graphites," Proceedings of the Fifth Conference on Carbon, Pergamon Press, New York, Vol. 2, pp. 335-346, 1963.

32. R. H. de Vere, V. Fidleris, G. M. Jenkins, and J. W. Phillips. "The Briquetting of Graphite," Powder Metal1., №. 11, 23, 1963.

33. W. V. Goedde1, G. R. Tully, Jr., and R. A. Meyer, "The Use of Graphite in High-Temperature Nuclear Fuel Elements, "Proceedings of the Fifth Conference on Carbon, Pergamon Press, New York, Vol. 2, pp. 347-377, 1963.

34. J. L. White and R. J. Price, "Hot-Working of Graphite for Graphite-Matrix Nuclear Fuels," Carbon, 2, 327, 1965.

35. J. L. White and J. M. Pontelandolfo, "Graphite-Carbide Materials Prepared by Hot-Working with a Dispersed Liquid-Carbide Phase," Carbon, 4, 305, 1966.

36. J. L. White and J. M. Pontelandolfo, "HWLC Graphites Prepared by HotWorking Extruded Stock," Carbon, 6, 1, 1968.

37. J. L. White and J. Koyama, "Graphitic Materials Hot-Worked with a Dispersed Liquid Carbide: Thermal and Electrical Conductivity," J. Am. Ceram. Soc., 51, 395, 1968.

38. R. B. Matthews, D. B. Fischbach, and G. M. Jenkins, "Compaction and Hot Working of Natural Graphite-Molybdenum Carbide Composites," Third Conference on Industrial Carbons and Graphite, Soc. Chem. Ind., London, pp. 515-519, 1971 .

39. E. Fitzer and B. Kegel, "Reaktionen von Kohlenstoffgesattigter Vanadiumcarbidschmelze mit Ungeordnetem Kohlenstoff (Beitrag zur Katalytischen Graphitierung)," Carbon, 6, 433, 1968.

40. F. J. Derbyshire, A. E. B. Presland, and D. L. Trimm, "Graphite Formation by the Dissolution-Precipitation of Carbon in Cobalt, Nickel, and Iron," Carbon, 13, 111, 1975. 
41. Tokiti Noda, "Crystal Growth and Graphitization," Carbon, 18, 3, 1980.

42. Isao Mochida, Keiko Kudo, Noriyoshi Fukuda, Kenjiro Takeshita, and Ryohei Takahashi, "Carbonization of Pitches - IV. Carbonization of Polycyclic Aromatic Hydrocarbons Under the Presence of Aluminum Chloride Catalyst," Carbon, 13, 135, 1975.

43. Isao Mochida, Ei-ichi Nakamura, Keiko Maeda, and Kenjiro Takeshita, "Carbonization of Aromatic Hydorcarbons - III. Carbonization Catalyzed by Alkali Metals," Carbon, 13, 489, 1975.

44. Isao Mochida, Ei-ichi Nakamura, Keiko Maeda, Kenjiro Takeshita, and Toru Hoshino, "Carbonization of Aromatic Hydrocarbons - V. Microscopic Features of Carbons Obtained by the Aid of Catalysts, " Carbon, 14, 341, 1976.

45. Isao Mochida, Shin-ichi Inoue, Keiko Maeda, and Kenjiro Takeshita, "Carbonization of Aromatic Hydrocarbons - VI. Carbonization of Hetrocycl ic Compounds Catalyzed by Aluminum Chloride," Carton, 15, 9, 1977.

46. Isao Mochida, Keishi Otsuka, Keiko Maeda, and Kenjiro Takeshita, "Carbonization of Aromatic Hydrocarbons - VII. The Role of Active Carbonizing Species in the Catalytic Carbonization of Pyrene, " Carbon, 15, 239, 1977.

47. Isao Mochida, Takashi Ando, Keiko Maeda, and Kenjiro Takeshita, "Catalytic Carbonization of Aromatic Hydrocarbons - VII. Carbonization Mechanism of Hetrocyclic Nitrogen Compounds Catalyzed by Aluminum Chloride," Carbon, 16, 453, 1978.

48. Isao Mochida, Ryosuke Ohtsubo, Kenjiro Takeshita, and Harry Marsh, "Catalytic Graphitization of Graphitizable Carbon by Chromium, Manganese, and Molybdenum Oxides," Carbon, 18, 25, 1980.

49. I. Mochida, R. Ohtsubo, K. Takeshita, and Harry Marsh, "Catalytic Graphitization of Non-Graphitizable Carbon by Chromium and Manganese Oxides," Carbon, 18, 117, 1980.

50. Isao Mochida, Takashi Ando, Keiko Maeda, Horoshi Fujitsu, and Kenjiro Takeshita, "Catalytic Carbonization of Aromatic Hydrocarbons - IX. Carbonization Mechanism of Hetrocycl ic Sulfur Compounds Leading to the Anisotropic Coke," Carbon, 18, 131, 1980.

51. H. P. Boehm, "Chemical Identification of Surface Groups," in Advances in Catalysis, Vol. 16, Academic Press, New York, (1966), pp. 179.

52. B. B. Boonstra, "Fillers: Carbon Black and Nonblack," chapter 3 of Rubber Technology, (edited by Maurice Morton), Van Nostrand Reinhold, New York (1973) pp. 51-86. 
53. B. R. Puri, "Surface Complexes on Carbons," in Chemistry and Physics of Carbon, Vol. 6, (edited by P. L. Walker, Jr.), Marcel Dekker, New York (1970) pp. 191-282.

54. V. Raskovic and S. Marinkovic, "Processes in Sulfur Dioxide Treatment of PAN Fibers," Carbon, 16, 351, 1978.

55. W. M. Gaylord, "Carbon and Graphite," Ind. Eng. Chem., 51, 1161, 1959.

56. Charles L. Mantel1, Carbon and Graphite Handbook, Interscience Publishers, New York, NY, 1968.

57. A. Hilliard, "Impermeable Graphite for Chemical Plant," Third Conference on Industrial Carbons and Graphite, Soc. Chem. Ind., London, pp. 562-565, 1971.

58. P. L. Walker, Jr., and F. Rusinko, Jr., "Effect of Impregnation and Subsequent Burn-0ff on Physical Properties of Graphitized Carbon Rods," Proc. of the Third Conference on Carbon, Pergamon Press, London, pp. 633-642, 1959.

59. H. H. W. Losty, "The Effect of Impregnation and Heat Treatment on the Physical Properties of Graphite," Proc. of the Fourth Conference on Carbon, Pergamon Press, London, pp. 671-681, 1960.

60. H. H. W. Losty, "The Strength of Graphite," Proc. of the Fifth Conference on Carbon, Pergamon Press, London, Vol. 1, pp. 519-532, 1962.

61. L. W. Graham, D. R. Perels, and W. J. Greenwood, "Recent Developments in Graphite Impregnation," Proc. of the Fifth Conference on Carbon, Pergamon Press, London, Vol. 1, pp. 567-574, 1962.

62. K. J. Huttinger and U. Rosenblatt, "On the Pyrolysis Behavior of Coal Tar and Petroleum Pitches Under Pressure," 12th Biennial Conference on Carbon, CONF-750410, University of Pittsburgh, pp. 269-270, July 1975.

63. W. Chard and H. Keck, "Carbon Microstructural Development at High Pressures," 13th Biennial Conference on Carbon, CONF-770701, pp.-212-213, July 1977.

64. H. Dietrich and L. E. McAllister, "Practical High Density Graphite Materials for Aerospace and Commercial Applications," 14th Biennial Conference on Carbon, Pennsylvania State University, pp. 85-86, June 1979.

65. E. Fitzer and H. Tillmanns, "Binder Materials Modified by Sulfur," 12th Biennial Conference on Carbon, CONF-750410, University of Pittsburgh, pp. 217-218, July 1975.

66. R. L. Bickerdike, A. R. G. Brown, G. Hughes, and H. Ranson, "The Deposition of Pyrolytic Carbon in the Pores of Bonded and Unbonded Carbon Powders, "Proceedings of the Fifth Conference on Carbon, Pergamon Press, London, VoT. 1, pp. 575-582, 1962. 
67. R. J. Bard, et al., "Development of Particles Coated with Pyrolytic Carbon - IV. Coatings from Various Hydrocarbons at Low Temperatures," LA-3767, July 1967.

68. R. J. Bard, H. R. Baxman, J. P. Bertino, and J. A. O'Rourke, "Pyrolytic Carbons Deposited in Fluidized Beds at 100 to $1400^{\circ} \mathrm{C}$ from Various Hydrocarbons," Carbon, $6,603,1968$.

69. J. L. Kaae, "Structure and Mechanical Properties of Isotropic Pyrolytic Carbons Deposited Below $1600^{\circ} \mathrm{C}, "$ J. Nucl. Mater., 38, 42, 1971.

70. J. M. Blocher, Jr., and I. E. Campbe11, "Carbide Coatings for Graphite," Proc. of the Second United Nations International Conference on the Peaceful Uses of Atomic Energy, U.N., Geneva, Vol. 7, pp. 374-378, 1958.

71. D. A. Schulz, P. H. Higgs, and J. D. Cannon, "Research and Development on Advanced Graphite Materials, Volume XXXIV, Oxidation-Resistant Coatings for Graphite," WADD TR 6172, July 1964.

72. A. J. Owen, K. W. Sykes, D. J. D. Thomas, and P. White," The Reactions of Carbon with Sulphur Compounds. Part 2. The Reaction of Hydrogen Sulphide with Various Types of Carbon," Trans. Faraday Soc., 49, 1198, 1953.

73. K. W. Sykes and P. White, "The Reactions of Carbon and Sulphur Compounds. Part 4. Adsorption of Gaseous Sulphur and Carbon Disulphide by Charcoal," Trans. Faraday Soc., 52, 660, 1956.

74. H. E. Blayden and J. W. Patrick, "Sol id Complexes of Carbon and Sulphur - I. Sulphurized Polymer Carbons," Carbon, 5, 533, 1967.

75. Balwant Rai Puri and Ram Singh Hazra, "Carbon-Sulphur Surface Complexes on Charcoal," Carbon, 9, 123, 1971.

76. R. A. Meyer and J. C. Bokros, "Graphite-Metal and Graphite-Molten-salt Systems," Chapter 15, of Nuclear Graphite, (edited by R. E. Nightingale), Academic Press, New York (1962) pp. 445-463.

77. J. C. Bokros, "Graphite-Metal Compatibility at Elevated Temperatures," J. Nucl. Mater., $3,89,1961$.

78. F. Lanza, H. Burg, S. Giuliani, M. Hoepper, and G. Marengo, "Physical Properties of Metal-Impregnated Graphite," Third Conference on Industrial Carbons and Grpahite, Soc. Chem. Ind., London, pp. 405-410, 1971.

79. F. Demuth and E. Fitzer, "Reaction Brazing of Polycrystalline Graphite by High-Melting Solders," 11th Biennial Conference on Carbon, CONF-730601, p. 128, June 1973. 
80. Y. Ando, T. Fujimura, M. Nomaguchi, and Y. Inoue," Development of Bonding Methods for Graphite Materials," Proc. of the Third United Nations Inter national Conference on the Peaceful Uses of Atomic Energy, U.N., Geneva, Vol. 9, pp 365-369, 1965.

81. D. A. Canonico, N. C. Cole and G. M. Slaughter, "Direct Brazing of Ceramics, Graphite and Refractory Metals," Welding J., 56(8), 31, 1977.

82. P. L. Walker, Jr. and S. B. Seeley, "Fine Grinding of Ceylon Natural Graphite," Proc. of the Third Conference on Carbon, Pergamon Press, London, pp 481-494, 1959.

83. R. J. Bobka, "Chemical Characteristics of Carbon Brush Wear Dust," Proc. of the Fifth Conference on Carbon, Pergamon Press, London, Vol 2, pp. 287-293, 1962 .

84. W. J. Gray, "Reaction of Graphite With Water and Its Implications for Radioactive Waste Storage," Rad. Waste Mgmt., 1, 105, 1980.

85. M. R. Nu11, W. W. Lozier, and A. W. Moore, "Thermal Diffusivity and Thermal Conductivity of Pyrolytic Graphite from 300 to $2700^{\circ} \mathrm{K}$, " Carbon, $11,81,1973$.

86. R. Taylor, K. E. Gilchrist and L. J. Poston, "Thermal Conductivity of Polycrystalline Graphite," Carbon, 6, 537, 1968.

87. J. L. Jackson, "Physical Property Measurements on NPR Graphite II. Unirradiated Core Graphite," HW-70877, August 1961.

88. G. A. Gogotsi, Ya. L. Groushevsky and K. K. Strelov, "The Significance of Non-Elastic Defromation in the Fracture of Heterogeneous Ceramic Materials, " Ceramurgia Intern., 4, 113, 1978.

89. R. M. Bushong and E. A. Neel, "Properties of High Density, Recrystallized Graphite, "Proceedings of the Fifth Conference on Carbon, Pergamon Press, London, Vo1. 1, pp. 595-599, 1962.

90. E. Y. Robinson, "ATJ-S Graphite Data Base: Uniaxial Properties," 12th Biennial Conference on Carbon, CONF-750410, University of Pittsburgh, pp. 101-4, JuTy 1975.

91. J. D. Buch, J. G. Crose, R. L. Holman and T. E. Mack, "Correlation of a Physically Based Statistical Theory of Fracture with Full Scale Ground Tests of Reentry Nosetips," 13th Biennial Conference on Carbon, CONF-770701, pp 355-356, Juity 1977.

92. A. G. Whittaker and J. S. Evangelides, "Influence of Carbon Polymorphs on Ablation of Graphitic Materials, 13th Biennial Conference on Carbon, CONF-770701, p. 410, July 1977. 
93. P. G. Ruoppe, L. D. Loch, and L. A. Joo, "Production Scale Up of the Graphnol N Process," 13th Biennial Conference on Carbon, CONF-770701, pp 426-427, July 1977 .

94. R. J. Edwards and H. S. Starrett, "Thermal and Mechanical Properties of Graphnol N3M Graphite," 14th Biennial Conference on Carbon, Pennsylvania State University, pp. 334-335, June 1979.

95. Mineral Commodity Summaries, 1980, U.S. Bureau of Mines, January 1980.

96. Metal Statistics, 1979, Fairchild Publications, New York, NY, 1979.

97. G. L. Tingey and W. D. Felix, Radiolytic Gas Generation from Calcined Nuclear Waste, BNWL-2381, Pacific Northwest Laboratory, Richland, WA 99352, August 1977. 


\section{DISTRIBUTION}

No. of

Copies

OFFSITE

A. A. Churm

DOE Chicago Patent Group

9800 South Cass Avenue

Argonne, IL 60439

27 DOE Technical Information Center

R. E. Cunningham

Office of Nuclear Safety

Materials and Safeguards

Room 562

Nuclear Regulatory Commission

7915 Eastern Avenue

Silver Springs, MD 20910

3 Division of Waste Management Nuclear Regulatory Commission Washington, DC 20555

ATTN: J. B. Martin

D. M. Rohrer

R. Dale Smith

W. E. Mott

DOE Division of Environmenta] Control Technology

Washington, DC 20545

13 DOE Office of Nuclear Waste Management

Washington, DC 20545

ATTN: C. R. Cooley, NE-331, GTN

G. H. Daly, NE-322, GTN

J. D. Dieckhoner, NE-321, GTN

C. H. George, NE-330, GTN

C. A. Heath, NE-330, GTN

M. L. Lawrence, NE-340, GTN

D. J. McGoff, NE-320,GTN

S. Meyers/R. Romatowski, NE-30, GTN

G. Oertel, NE-320, GTN

A. F. Perge, NE-30, GTN
No. of

Copies

OFFSITE
R. B. Chitwood

DOE Division of Nuclear Power Development

Washington, DC 20545

W. G. Belter

DOE Division of Biomedical and Environmental Research

Earth Sciences Branch

Washington, DC 20545

W. A. Brobst

DOE Division of Environmental Control Technology

Washington, DC 20545

S. A. Mann

DOE Chicago Operations and Region Office

Argonne, IL 60439

J. 0. Neff

Department of Energy

Columbus Program Office

505 King Avenue

Columbus, $\mathrm{OH} 43201$

3 DOE Idaho Operations Office

550 2nd St.

Idaho Falls, ID 83401

ATTN: J. P. Hamric

J. W. Peel

J. B. Whitsett 
No. of

Copies

3 DOE Oak Ridge Operations Office P.0. Box E Oak Ridge, TN 37830

ATTN: S. W. Ahrends (2)

D. Large

4 Oak Ridge National Laboratory P.0. Box $X$ Oak Ridge, TN 37830

ATTN: W. P. Eatherly

A. L. Lotts (3)

4 Oak Ridge National Laboratory P.0. Box Y

Oak Ridge, TN 37830

ATTN: R. E. Blanco

J. 0. Blomeke

W. J. Lackey

T. Lindemer

2 Central Research Library

Document Reference Section

Oak Ridge National Laboratory (DOE)

Oak Ridge, TN 37830

Los Alamos Scientific Laboratory

P.0. Box 1663

Los Alamos, NM 87544

2 DOE Savannah River Operations Office

P.0. Box A

Aiken, SC 29801

ATTN: W. B. Wilson

R. P. Whitfield

3 Exxon Nuclear Idaho

P.0. Box 2800

Idaho Falls, ID 83401

ATTN: G. L. Ritter

J. R. Berreth

D. A. Knecht
No. of

Copies

$2 E G$ and $G$ Idaho

P.0. Box 1625

Idaho Falls, ID 83415

ATTN: A. L. Ayers

R. L. Tallman

S. G. Harbinson

DOE San Francisco Operations

1333 Broadway

Oakland, CA 94612

3 DOE Albuquerque Operations Office P.0. Box 5400

Albuquerque, NM 87185

ATTN: R. Y. Lowrey (2)

A. L. Taboas

2 Allied-General Nuclear Services

P.0. Box 847

Barnwe11, SC 29812

ATTN: J. A. Buckham

A. Williams

3 Argonne National Laboratory

9700 South Cass Avenue

Argonne, IL 60439

ATTN: J. L. Jardine

J. H. Kittel

M. J. Steindler/

L. E. Trevorrow

2 Brookhaven National Laboratory

Reference Section

Information Division

Upton, Long Island, NY 11973

D. G. Schweitzer

Brookhaven National Laboratory

Upton, NY 11973

Combustion Division

Combustion Engineering, Inc.

Windsor, CT 06095 
No. of

Copies

2 Battelle Memorial Institute Office of Nuclear Waste Isolation 505 King Avenue

Columbus, $\mathrm{OH} 43201$

ATTN: W. Carbiener Beverly Rawles

2 Battelle Memorial Institute 505 King Avenue

Columbus, OH 43201

ATTN: M. F. Browning Research Library

2 Rockwel1 International

Rocky Flats Plant

P.0. Box 464

Golden, CO 80401

ATTN: P. G. Hagan

E. Vejvoda

2 A. B. Martin

Rockwel1 International

8900 DeSoto Avenue

Canoga Park, CA 91304

5 E. I. du Pont de Nemours Co. Savannah River Laboratory

Aiken, SC 29801

ATTN: M. D. Boersma

R. G. Garvin

R. Maher

D. L. McIntosh

S. W. O'Rear

R. Williams

Electric Power Research Institute 3412 Hillview Avenue

P.0. Box 10412

Palo Alto, CA 94304

Environmental Protection Agency

Technological Assessment Division (AW-559)

Office of Radiation Programs

U.S. Environmental Protection Agency

Washington, DC 20460
No. of

Copies

2 General Atomic Co.

P.0. Box 81608

San Diego, CA 92138

ATTN: G. B. Engle

J. L. Kaae

R. G. Barnes

General Electric Company

175 Curtner Avenue

(M/C 160)

San Jose, CA 95125

L. H. Brooks

Gulf Energy and Environmental Systems

P.0. Box 81608

San Diego, CA 92138

C. J. Kershner

Monsanto Research Corporation

Mound Laboratory

P.0. Box 32

Miamisburg, $\mathrm{OH} 45342$

J. P. Duckworth

Plant Manager

Nuclear Fuels Services, Inc.

P.0. Box 124

West Valley, NY 14171

J. L. Larocca, Chairman

Engineering Research and

Development Authority

Empire State Plaze

Albany, NY 12223

3 J. Campbe 11

Lawrence Livermore Laboratory

P.0. Box 808

Livermore, CA 94550

Vitreous State Laboratory

The Catholic University of America

Washington, D.C. 20017

ATTN: P. B. Macedo

Keane Hall 
R. G. Kepler

Organic and Electronic

Dept. 5810

Sandia Laboratories

Albuquerque, NM 87185

J. W. Bartlett

The Analytical Sciences Corp.

6 Jacob Way

Reading, MA 01867

J. R. Potter

Chem-Nuclear Systems, Inc.

P.0. Box 1866

Bellevue, WA 98009

R. G. Post

College of Engineering

University of Arizona

Tucson, AZ 85721

L. L. Hench

Dept. of Materials Science and Engineering

University of Florida

Gainesville, FL 32611

H. Palmour, III

2140 Burlington Engineering Laboratories

North Carolina State University

Raleigh, NC 27607

D. E. Harrison

Westinghouse Electric Corporation

Penn Center, Bldg. 2

Box 355

Pittsburgh, PA 15230

R. Roy

202 Materials Research Laboratory

University Park, PA 16802

F. K. Pittman

3508 Sagecrest Terrace

Ft. Worth, TX 76109
J. G. Cline, General Manager

NYS Atomic and Space Development Authority

230 Park Avenue, Rm. 2425

New York, NY 10017

John Pomeroy

Technical Secretary

National Academy of Sciences

Committee of Radioactive Waste

Management

National Research Council

2101 Constitution Avenue

Washington, DC 20418

L. Henning

Electric Power Research Institute

3412 Hillview Avenue

P.0. Box 10412

Palo Alto, CA 94304

G. J. McCarthy

Department of Chemistry

North Dakota State University

Fargo, ND 58102

Rod Ewing

University of New Mexico

Albuquerque, NM 87131

R. A. Beall

U.S. Department of Interior

Bureau of Mines

Albany Research Center

1450 W. Queen Avenue

Albany, OR 87321

S. E. Logan

University of New Mexico

Albuquerque, NM 87131

Stewart Farber

New England Power Company

280 Melrose Street

Providence, RI 02901 
No. of

Copies

D. B. Stewart

U.S. Department of Interior 959 National Center Geological Survey

Reston, VA 22092

Professor Guna Salvaduray

Materials Engineering

San Jose State University

San Jose, CA 95192

B. Adams

Corning Glass Works

Technical Staffs Division

Corning, NY 14830

\section{ONSITE}

4 DOE Richland Operations Office

P. A. Craig (2)

R. E. Gerton

H. E. Ransom

9 Rockwell Hanford Operations

H. Babad

R. A. Deju

D. R. Gustavson

M. J. Kupfer

I. E. Reep

W. W. Schulz

D. D. Wodrich (3)

\section{Exxon}

Richland, WA 99352

2 Joint Center for Graduate Study

J. Cooper

L. C. 01 sen
No. of

Copies

UNC United Nuclear Industries

F. H. Bouse, Document Control

Westinghouse Hanford Company

A. G. Blasewitz

69 Pacific Northwest Laboratory

W. J. Bjorklund

H. T. Blair

W. F. Bonner

D. J. Bradley

D. W. Brite

R. A. Brouns

C. Q. Buckwalter

J. L. Buelt

L. R. Bunnell

J. R. Carrel1

J. G. Carter

L. A. Chick

T. D. Chikalla

M. 0. Cloniger

R. D. Dierks

G. J. Exarhos

W. J. Gray

W. E. Gurwell

C. R. Hann

P. E. Hart

0. F. Hill

L. K. Hol ton

J. H. Jarrett

R. S. Kemper

D. E. Knowlton

C. A. Knox

L. T. Lakey

D. E. Larson

R. 0. Lokken

J. L. McElroy

G. L. McVay

G. B. Mellinger

J. E. Mendel

F. A. Miller

W. C. Morgan (5)

R. D. Nelson

J. F. Nesbitt 
No. of

Copies

R. E. Nightingale

K. H. Oma

R. D. Peters

A. M. Platt

F. D. Roberts

W. A. Ross

J. M. Rusin

R. J. Serne

J. W. Shade

D. H. Siemens

S. C. Slate
No. of

Copies

D. M. Strachan

G. L. Tingey

C. L. Timmerman

R. L. Treat

R. P. Turcotte (2)

H. H. Van Tuy 1

J. W. Wald

W. J. Weber

R. E. Westerman

Technical Information (5)

Publishing Coordination (2) 